\title{
Retrospective analytical study of total abdominal hyeterectomy for benign gynaecological conditions
}

\author{
Varuna Pathak, Pallavi Singh*, Archna Tripathi
}

Department of Obstetrics and Gynecology, Gandhi Medical College, Bhopal, Madhya Pradesh, India

Received: 06 March 2017

Accepted: 14 March 2017

\author{
*Correspondence: \\ Dr. Pallavi Singh, \\ E-mail: pal.dr.84@gmail.com
}

Copyright: (c) the author(s), publisher and licensee Medip Academy. This is an open-access article distributed under the terms of the Creative Commons Attribution Non-Commercial License, which permits unrestricted non-commercial use, distribution, and reproduction in any medium, provided the original work is properly cited.

\section{ABSTRACT}

Background: Hysterectomy, which is one of the most common surgeries performed on women, dates back to ancient time. This retrospective study was done to determine a baseline data on various indications for total abdominal hysterectomy for benign gynaecological conditions, most common presenting symptoms, and socio-economic status and their histopathology correlation.

Methods: This retrospective study was performed in the department of Obstetrics and gynaecology, in collaboration with Department of Pathology, Gandhi Medical College, Bhopal. Baseline data were collected from inpatient files and histopathology reports to determine the indication for surgery, pattern of gynaecological diseases, and distribution with respect to age, parity, rural, urban, socio-economic status and final histopathology correlation. Histopathology reports were collected from Department of Pathology.

Results: Majority of women undergone TAH for benign gynaecological diseases were in age group of 40-49 years $[\mathrm{n}=341(48.99 \%$ cases $)]$, multi para and from urban areas $(57.26 \%)$. most common indication for TAH is fibroid uterus $[\mathrm{n}=347(49.85 \%)]$. The most common mode of presentation is excessive prolonged frequent bleeding per vagina $(58.14 \%)$. Most common histopathology reports of TAH were leiomyoma with chronic cervicitis $\{n=347$ $(49.78 \%)\}$.

Conclusions: Majority of women undergoing for TAH for benign gynaecological conditions have great satisfaction as they got relieved from their complaints and very minimum post-operative complications, but their long term outcome are still debatable.

Keywords: Abnormal uterine bleeding, Histopathology reports, Post-menopausal bleeding, Total abdominal hysterectomy

\section{INTRODUCTION}

Hysterectomy word derived from Greek word hystero 'uterus', 'ektome,' 'cutting out of' is the surgical removal of uterus. Hysterectomy, which is the most common surgical procedures performed on women, is mainly associated with noncancerous conditions. ${ }^{1}$

Though a number of minimally invasive surgical options for hysterectomy do exist now and are promising like endometrial ablation, thermal balloon therapy and uterine artery embolization, but restricted availability, poor knowledge, high cost and need follow-up limit them from being widely used. Therefore hysterectomy, abdominal or vaginal, still remains the widely accepted and practised treatment of choice for majority of gynaecological diseases. In developing countries, especially in rural areas, due to limited resources available women usually present very late to health care facilities and desire a permanent cure to their diseases at the cheapest rates available. $^{2}$ 
This retrospective study was done to determine a baseline data on various indications for total abdominal hysterectomy for benign gynaecological conditions, most common presenting symptoms, and socio-economic status and their histopathology correlation.

\section{METHODS}

This retrospective study was performed in the department of Obstetrics and gynaecology, in collaboration with Department of Pathology, Gandhi Medical College, Bhopal.

This is a tertiary level teaching institute catering to the needs of adjoining rural population.

All women (reproductive age group or post-menopausal) who underwent major gynaecological surgery (total abdominal hysterectomy with or without salpingooophorectomy) were included in this study since January 2013 to December 2015.

Emergency obstetric hysterectomy and hysterectomy for malignant diseases were excluded.

The ethical approval of this work was obtained from ethical committee of Gandhi Medical College Bhopal.

Baseline data were collected from inpatient files and histopathology reports to determine the indication for surgery, pattern of gynaecological diseases, and distribution with respect to age, parity, rural, urban, socio-economic status and final histopathology correlation.

Histopathology reports were collected from Department of Pathology.

Pre-operative information including patient demography, major medical history, and indications for hysterectomy, immediate post-operative morbidities and histopathology correlations were collected and analysed by Performa.

\section{Exclusion criteria}

- Suspected malignant gynaecological conditions

- Obstetric hysterectomy

- Vaginal hysterectomy

\section{RESULTS}

The total number of Hysterectomy performed for benign gynaecological disorders during the three year period was 1112 , out of which 696 were abdominal hysterectomies for benign gynaecological conditions, which accounts for $62.59 \%$.

Total vaginal hysterectomies were 416 (37.41\%). Out of TAH $55.06 \%(n=383)$ were TAH with BSO followed by
$34.36 \% \quad(n=239)$ were TAH with USO followed by $10.57 \%(\mathrm{n}=74)$ were only TAH.

The socio demographic characteristics was shown in Table 1 and Table 2 revealed that the majority of women who were undergone hysterectomy were in their fifth and forth decade of life. The mean age is 46.1 year with range from 20 to 65 years.

Table 1: Case distribution according to age for TAH.

\begin{tabular}{|lll|}
\hline Age & Number & Percentage \\
\hline 20-29 years & 25 & 3.52 \\
\hline 30-39 years & 293 & 42.29 \\
\hline 40-49 years & 341 & 48.99 \\
\hline 50-59 years & 34 & 4.84 \\
\hline$>60$ years & 3 & 0.44 \\
\hline
\end{tabular}

Total number $\mathrm{n}=696$

Table 2: Case distribution of TAH according to parity.

\begin{tabular}{|lll|}
\hline Parity & Number & Percentage \\
\hline Nulligravida & 22 & 3.08 \\
\hline Para1 & 32 & 4.40 \\
\hline Para2 & 88 & 12.77 \\
\hline Para3 & 116 & 16.74 \\
\hline Para4 & 224 & 32.15 \\
\hline Para5 & 162 & 23.34 \\
\hline Para6 & 28 & 3.96 \\
\hline Para7 & 18 & 2.64 \\
\hline Para8 & 06 & 0.88 \\
\hline
\end{tabular}

Total number $\mathrm{n}=696$

Table 3: Case distribution of TAH according to demographic distribution.

\begin{tabular}{|ll|l|}
\hline Demography & Number & Percentage \\
\hline Urban & 399 & $57.26 \%$ \\
\hline Rural & 297 & $42.73 \%$ \\
\hline
\end{tabular}

Total number $\mathrm{n}=696$

Table 4: Case distribution of TAH according to socioeconomic status.

\begin{tabular}{|llll|}
\hline Class & Type & No. of cases & Percentage \\
\hline I & Upper & 6 & 0.85 \\
\hline II & Upper middle & 34 & 4.89 \\
\hline III & Middle & 138 & 19.83 \\
\hline IV & Lower middle & 312 & 44.83 \\
\hline V & Lower & 206 & 29.60 \\
\hline
\end{tabular}

Total number $\mathrm{n}=696$

\section{Fibroid uterus}

The most common indication for TAH is Fibroid uterus and their correlation with age group, parity and HPR described in Tables 9,10 and Figure 1. Total Number of 
Cases for Fibroid Uterus Indication (n) is 347 Out of 696 i.e. $(49.85 \%)$.

Table 5: Case distribution according to indications for TAH in benign gynaecological conditions.

\begin{tabular}{|lll|}
\hline Indication & No & Percentage \\
\hline Fibroid uterus & 347 & 49.85 \\
\hline AUB & 77 & 11.06 \\
\hline Adenomyosis & 65 & 9.33 \\
\hline Ovarian mass & 62 & 8.90 \\
\hline Chronic cervicitis & 58 & 8.33 \\
\hline AUB with chronic cervicitis & 47 & 6.75 \\
\hline Endometrial polyp & 21 & 3.02 \\
\hline Post-menopausal bleeding & 13 & 1.86 \\
\hline Cervical fibroid & 06 & 0.9 \\
\hline Total number $\mathrm{n}=696$ & & \\
\hline
\end{tabular}

Table 6: Case distribution of TAH according to mode of presentation.

\begin{tabular}{|lcc|}
\hline Mode of presentation & No & Percentage \\
\hline $\begin{array}{l}\text { Excessive prolonged frequent } \\
\text { bleeding per-vagina with pain in } \\
\text { lower abdomen (menorrhagia and } \\
\text { poly menorrhoea) }\end{array}$ & 405 & 58.14 \\
\hline $\begin{array}{l}\text { Pain in lower abdomen with white } \\
\text { discharge per-vagina }\end{array}$ & 209 & 30.23 \\
\hline $\begin{array}{l}\text { Amenorrhoea with pain in } \\
\text { abdomen }\end{array}$ & 24 & 3.52 \\
\hline Mass in abdomen & 21 & 3.08 \\
\hline Dysmenorrhoea & 21 & 3.08 \\
\hline Post-menopausal bleeding & 16 & 2.32 \\
\hline
\end{tabular}

Total number $\mathrm{n}=696$

Table 7: Case Distribution of TAH according to HPR correlations.

\begin{tabular}{|c|c|c|}
\hline HPR & No & Percentage \\
\hline Leiomyoma with chronic cervicitis & 347 & 49.78 \\
\hline Chronic cervicitis & 159 & 22.84 \\
\hline Adenomyosis with chronic cervicitis & 63 & 9.25 \\
\hline $\begin{array}{l}\text { Simple serous cyst with chronic } \\
\text { cervicitis }\end{array}$ & 27 & 3.96 \\
\hline $\begin{array}{l}\text { Leiomyomatous polyp with chronic } \\
\text { cervicitis }\end{array}$ & 24 & 3.52 \\
\hline $\begin{array}{l}\text { Leiomyoma with Adenomyosis with } \\
\text { chronic certvicitis }\end{array}$ & 22 & 3.08 \\
\hline Leiomyoma & 15 & 2.21 \\
\hline Serous cyst adenoma & 09 & 1.32 \\
\hline Simple serous cyst & 09 & 1.32 \\
\hline Chocolate cyst & 06 & 0.88 \\
\hline Dermoid cyst & 06 & 0.88 \\
\hline $\begin{array}{l}\text { Chronic cervicitis with mucinous } \\
\text { cyst adenoma }\end{array}$ & 06 & 0.88 \\
\hline $\begin{array}{l}\text { Chocolate cyst with chronic } \\
\text { cervicitis }\end{array}$ & 03 & 0.44 \\
\hline
\end{tabular}

Total number $\mathrm{n}=696$
Observations and analysis for total abdominal hysterectomy according to indication

\section{Abnormal uterine bleeding}

Indication Abnormal Uterine Bleeding for TAH and its correlation with age group, parity and HPR described Tables 11, 12 and Figure 2. Total number of cases for abnormal uterine bleeding (n) is 77 out of 696 i.e. (11.06\%). Immediate post-operative morbidities associated with TAH for benign gynaecological diseases are:

Table 8: Case distribution of TAH according to complications.

\begin{tabular}{|llll|}
\hline Complication & $\begin{array}{l}\text { Unidentified } \\
\text { cause }\end{array}$ & 36 & 5.1 \\
\hline $\begin{array}{l}\text { Febrile morbidity } \\
\text { Urinary tract } \\
\text { infection }\end{array}$ & 70 & 10.2 \\
\hline $\begin{array}{l}\text { Wound } \\
\text { infection }\end{array}$ & 19 & 2.7 \\
\hline $\begin{array}{l}\text { Haemorrhage } \\
\text { requiring transfusion }\end{array}$ & 28 & 4 \\
\hline Resuturing & & 28 & 4 \\
\hline Urinary retention & 05 & 0.7 \\
\hline Deep vein thrombosis & & 01 & 0.1 \\
\hline Bladder injury & 00 & 00 \\
\hline Ureteric injury & & 00 & 00 \\
\hline Bowel injury & 00 & 00 \\
\hline No complications & & 509 & 73.2 \\
\hline Total number $\mathrm{n}=696$ & & \\
\hline
\end{tabular}

Table 9: Case distribution of TAH for fibroid uterus according to age.

\begin{tabular}{|lll|}
\hline Fibroid Uterus [Total $(\mathbf{n})-347(49.85 \%)]$ \\
\hline Age group & Number of cases & Percentage \\
\hline Less than 30 years & 03 & 0.88 \\
\hline 30 - 39 years & 166 & 47.78 \\
\hline 40- 49 years & 117 & 33.62 \\
\hline 50- 59 years & 61 & 17.72 \\
\hline
\end{tabular}

Table 10: Case distribution of TAH for fibroid uterus according to parity.

\begin{tabular}{|lll|}
\hline Fibroid Uterus & {$[$ Total $(\mathbf{n})-\mathbf{3 4 7}(\mathbf{4 9 . 8 5 \% )})$} \\
\hline Parity & Number of cases & Percentage \\
\hline Nulli para & 15 & 4.42 \\
\hline Para 1 & 09 & 2.65 \\
\hline Para 2 & 37 & 10.61 \\
\hline Para 3 & 62 & 17.69 \\
\hline Para 4 & 160 & 46.0 \\
\hline Para 5 & 46 & 13.27 \\
\hline Para 6 & 09 & 2.65 \\
\hline Para 7 & 03 & 0.88 \\
\hline Para 8 & 06 & 1.77 \\
\hline
\end{tabular}


Table 11: Case distribution of TAH for AUB according to age.

\begin{tabular}{|lll|}
\hline AUB [Total $77(11.06 \%)$ & \\
\hline Age group & Number of Cases & Percentage \\
\hline 30-39 years & 31 & 40 \\
\hline $40-49$ years & 46 & 60 \\
\hline
\end{tabular}

\section{Adenomyosis}

Indication Adenomyosis for TAH and its correlation with age group, parity and HPR described in Tables 13, 14 and Figure 3. Total Number of Cases for Adenomyosis (n) is 65 Out of 696 i.e. $(9.33 \%)$.
Table 12: Case distribution of TAH for AUB according to parity.

\begin{tabular}{|lll|}
\hline AUB [Total $77(\mathbf{1 1 . 0 6 \% )})$ & \\
\hline Parity & Number of cases & Percentage \\
\hline Para 1 & 03 & 4 \\
\hline Para 2 & 19 & 24 \\
\hline Para 3 & 19 & 24 \\
\hline Para 4 & 24 & 32 \\
\hline Para 5 & 03 & 04 \\
\hline Para 6 & 06 & 08 \\
\hline Para 7 & 03 & 04 \\
\hline
\end{tabular}

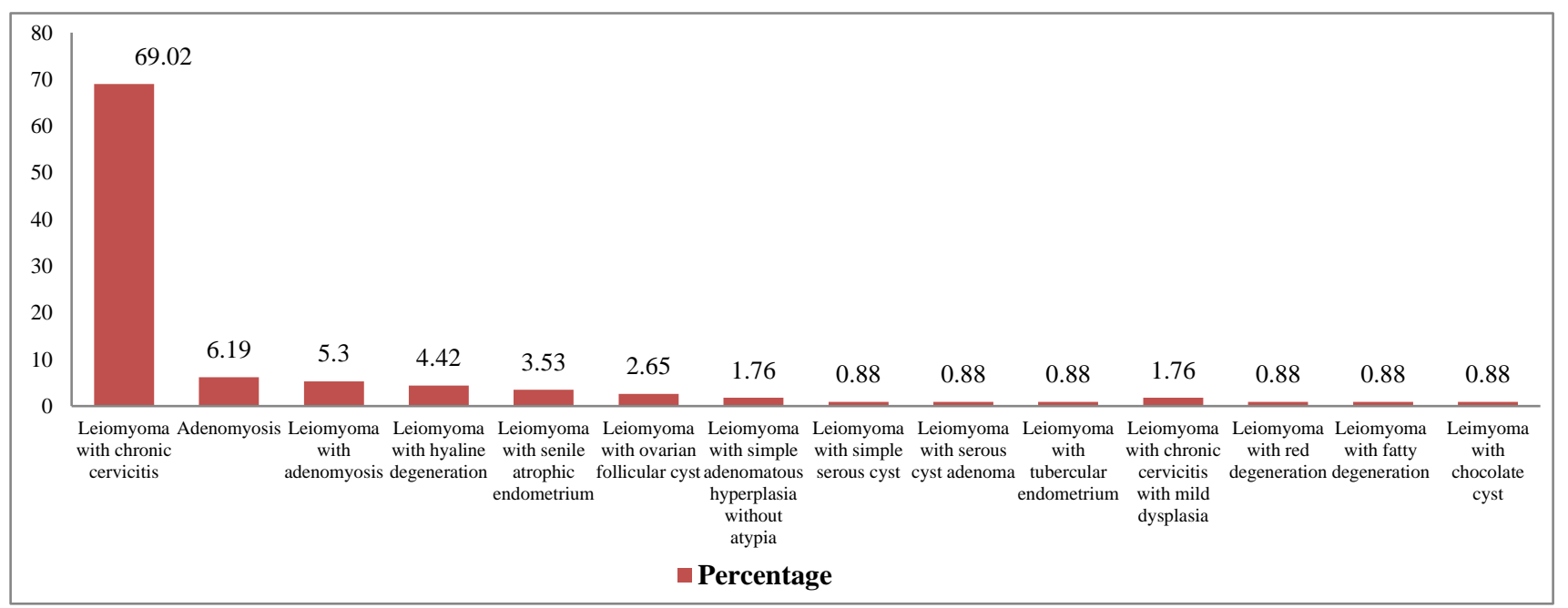

Figure 1: Case distribution of TAH for fibroid uterus according to HPR.

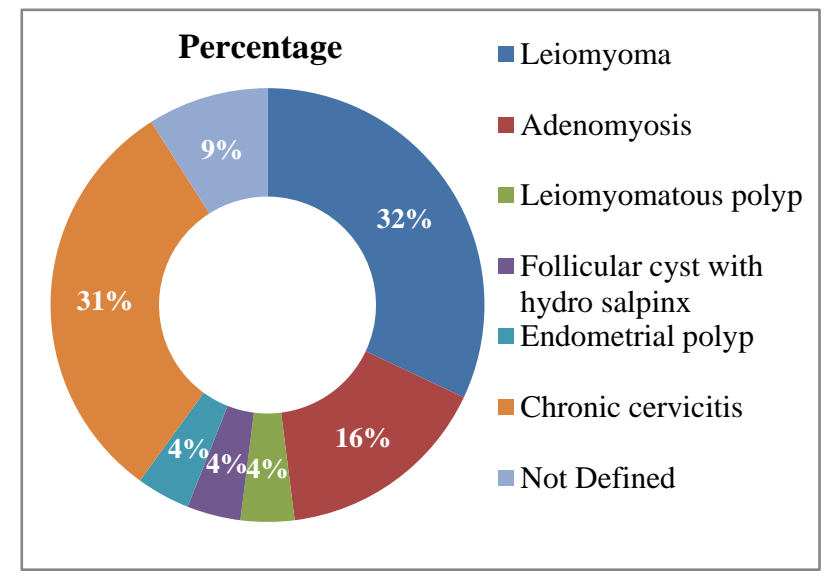

Figure 2: Case Distribution of TAH for AUB according to HPR.

Chronic cervicitis

Indication chronic cervicitis for TAH and its correlation with age group, parity and HPR described in Figure 4, 5 and 6. Total Number of Cases for chronic cervicitis (n) is 58 Out of 696 i.e. $(8.33 \%)$.

Table 13: Case distribution of TAH for adenomyosis according to Age.

\begin{tabular}{|lll|}
\hline Age group & Number of Cases & Percentage \\
\hline 30-39 years & 22 & 33.33 \\
\hline $40-49$ years & 40 & 61.90 \\
\hline 50-59 years & 03 & 4.76 \\
\hline
\end{tabular}

Total (n) is 65 Out of 696 i.e. $(9.33 \%)$.

Table 14: Case distribution according to parity in TAH for indication adenomyosis.

\begin{tabular}{|lll|}
\hline Parity & Number of cases & Percentage \\
\hline Para 1 & 03 & 4.76 \\
\hline Para 2 & 03 & 4.76 \\
\hline Para 3 & 16 & 23.81 \\
\hline Para 4 & 25 & 38.09 \\
\hline Para 5 & 12 & 19.04 \\
\hline Para 6 & 03 & 4.76 \\
\hline Para 8 & 03 & 4.76 \\
\hline
\end{tabular}




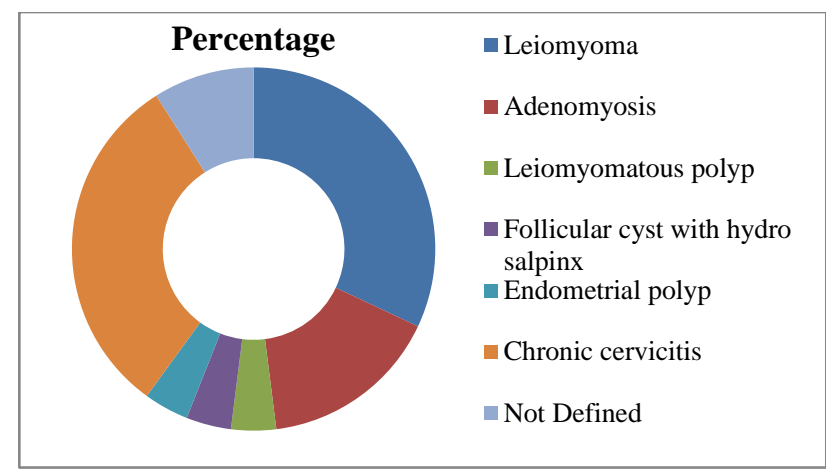

Figure 3: Case distribution according to HPR in TAH for indication adenomyosis.

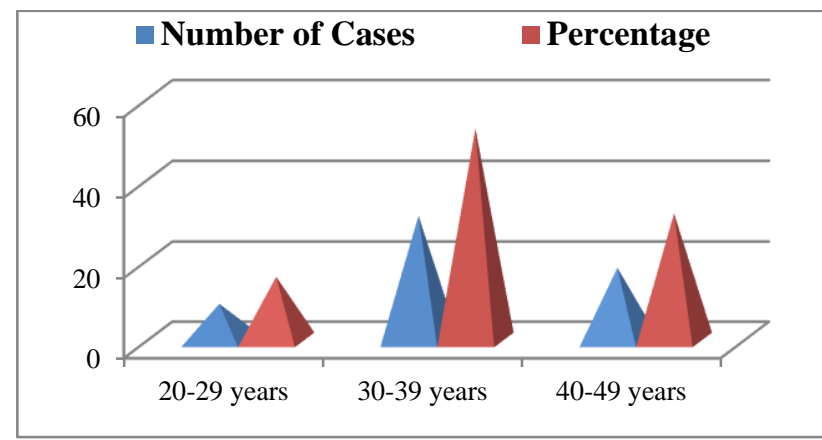

Total (n) is 58 Out of 696 i.e. $(8.33 \%)$

Figure 4: Case distribution according to age in TAH for indication chronic cervicitis.

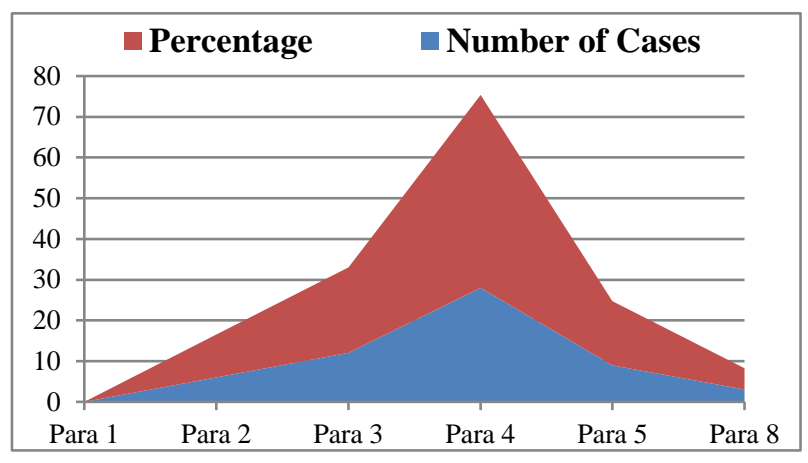

Figure 5: Case distribution according to parity in TAH for indication chronic cervicitis.

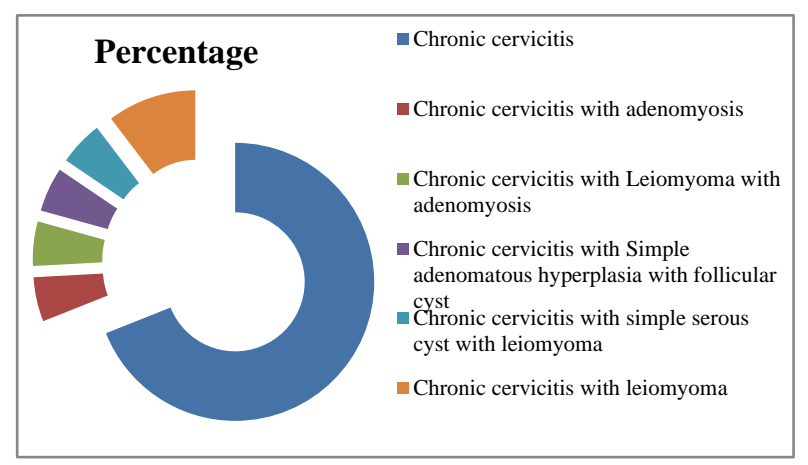

Figure 6: Case distribution according to HPR in TAH for indication chronic cervicitis.

\section{Post-menopausal bleeding}

Indication Post-menopausal Bleeding (PMB) for TAH was and its correlation with age group, parity and HPR described in following tables. Total Number of Cases for Post-menopausal Bleeding (PMB) (n) is 13 Out of 696 i.e. $(1.86 \%)$.

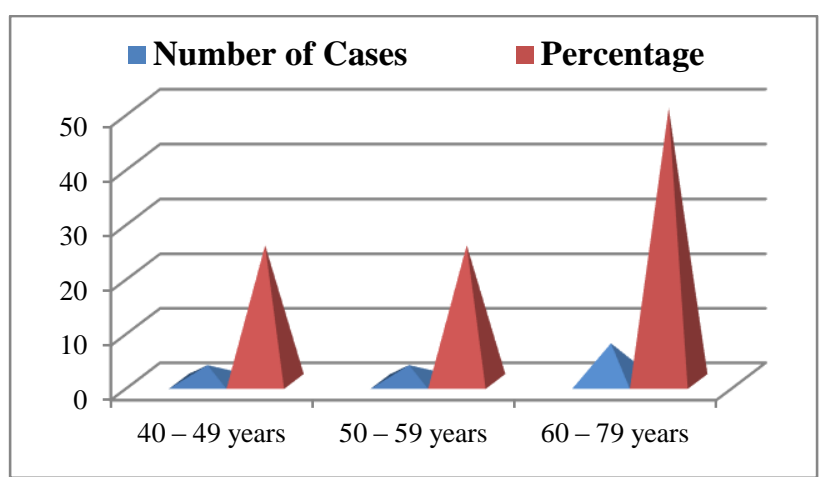

Total (n) is 13 Out of 696 i.e. $(1.86 \%)$.

Figure 7: Case distribution according to age in TAH for indication PMB.

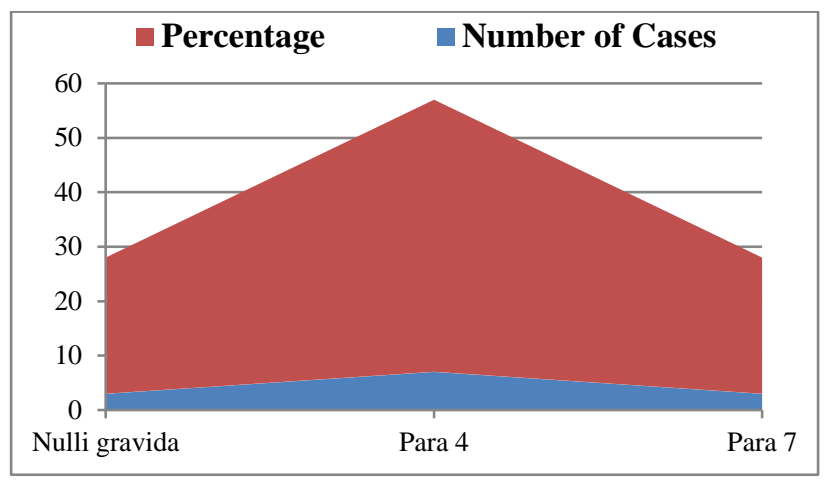

Figure 8: Case distribution according to parity in TAH for indication PMB.

\begin{tabular}{|l|l|}
\hline Percentage & Chronic cervicitis with \\
& intra epithelial \\
& neoplasia with \\
adenomyosis & \\
& Chronic cervicitis with \\
senile atrophic \\
endometrium with \\
endometrial polyp \\
Chronic cervicitis with \\
proliferative phase \\
endometrium \\
\end{tabular}

Figure 9: Case distribution according to HPR in TAH for indication PMB.

\section{DISCUSSION}

In our study Table 1 shows the majority of women undergone TAH for benign gynaecological diseases were 
in age group of 40-49 years [ $n=341(48.99 \%$ cases $)]$. This is consistent with study of Whiteman MK et al; which states the highest rate of hysterectomy is between the ages of 40-49 years with an average of 46.1 years. ${ }^{2}$ Leung PL et al, that states the age group distribution for TAH were $47 \pm 7$ years. Owerri Duke A et al. ${ }^{10,11}$ Majority of women who had hysterectomy were in their 5th to 6th decades of life. The mean age was $50.1 \pm 15.6$ years with a range of 30-75 years. In our study Table 2 shows the majority of women were grand multi para parity $4 n=224$ $(32.15 \%)$ and parity $5 \mathrm{n}=162(23.34$ This is consistent with study of Owerri Duke A. et al. which states that most of the women undergoing total abdominal hysterectomy were grand multi para, para 5 or more [66 $(50.40 \%)]$, para 3 and para 4 [40 (30.9\%)]. ${ }^{11}$ OmoleOhonsi A, et al. 2005 and Orji EO, et al, have similar conclusion in their study. ${ }^{12,13}$ In our study Table 3 shows the most of the women had undergone abdominal hysterectomy were hailing from urban areas \{n399 $(57.26 \%)\}$ which probably shows that the women from urban areas have more awareness about their health issues, easy accessibility to health facilities, follow-up and various treatment options. Table 4 Shows that most of the women undergone TAH belong to lower socio economic status. After distribution under modified Prasad system total percentage in Class IV (44.83\%) and Class V $(29.6 \%)$ is $74.83 \%$ of patients.

This is consistent Cooper R, Luke $\mathbf{J}$ et al. Which states that lower socio economic status is associated with increased hysterectomy rates. ${ }^{4}$ Table 5 of our study shows the most common indication for $\mathrm{TAH}$ is fibroid uterus $[\mathrm{n}=347(49.85 \%)]$ followed by abnormal uterine bleeding $[\mathrm{n}=77(11.06 \%)]$ followed by adenomyosis $[\mathrm{n}=65(9.33$ This is consistent with study of Whiteman MK, et.al. 2008 which state that uterine leiomyoma are consistently the leading indication for hysterectomy. (40.7\%) followed by endometriosis $(17.7 \%){ }^{3}$

Gimbel H, et al hvae similar conclusion. Leung P L, et al in this study most common indication for Hysterectomy was fibroid uterus $[\mathrm{n}=688(73.7 \%)]$ followed by menorrhagia $[\mathrm{n}=270(28.9 \%)] .{ }^{10,14}$ In this study Table 6 shows the most common mode of prsesntation is excessive prolonged frequent bleeding per vagina $(58.14 \%)$ followed by pain in lower abdomen with white discharge per vagina $(30.23 \%)$. This is consistent with the study of Chanderdeep Sharma, et al. In our study Table 7 shows the most common histopathology reports of TAH were leiomyoma with chronic cervicitis $\{n=347$ $(49.78 \%)\} .{ }^{15}$ Whiteman and Hills et al. This study states that leading indication for TAH was leiomyoma i.e. $40.7 \%$. Chanderdeep Sharma, et al in this study leiomyoma were found in $50.3 \%$ cases $[n=239]$ which is consistent in our study. ${ }^{2,15}$ In this study Table 8 shows that he most common complication of TAH is febrile morbidity (unidentified cause $5.1 \%$, UTI $10.2 \%$ and wound infection $2.7 \%$ ). This is consistent with the study of Ballard LA et al and Walters MD et al. In this study Table 9, 10 and Figure 1 shows most common indication
Fibroid uterus for TAH is and its correlation with age group, parity and HPR. ${ }^{8,9}$ Table 9 shows the correlation of fibroid uterus with age group of women. Majority of women requiring hysterectomy for fibroid uterus $[\mathrm{n}=347$ (49.78)] were in age group of 30 to 39 years $[n=166$ $(47.78 \%)$ ] followed by 40 to 49 years $[n=117(33.62 \%)]$. Peddada SD, et al. This study states that incidence of fibroid increases with age, 4.3 per 1000 women years for 25-29 years old and 22.5 for 40 to 44 years old. ${ }^{16}$ Table 10 shows that women undergone TAH for Fibroid uterus were most commonly in parity $4[n=160(46.0 \%)]$.

From Table 11, 12, and Figure 2 shows the distribution of cases of AUB according to age, parity and HPR correlation. The abnormal uterine bleeding is the second most common indication for $\mathrm{TAH}$ in our study i.e. $11.01 \%(\mathrm{n}=77)$. AUB is common indication for TAH worldwide 9 to 14 percent in Hallberg $\mathrm{L}$, et al and Varygas JM, et al. In Chanderdeep Sharma, et al the study shows the prevalence of AUB is $8.8 \%$. In this study Table 11 show the most common age group of women requiring hysterectomy for AUB is 40 to 49 years i.e. similar to study of Chanderdeep Sharma, et al In this study, Figure 2 shows HPR examination of uterus of women undergoing for TAH for AUB shows $32 \%$ leiomyoma followed by $16 \%$ adenomyosis, $4 \%$ leiomyomatous polyp and $31 \%$ chronic cervicitis In our study Table 13, 14 and Figure 3 shows distribution of cases of Adenomyosis according age, parity and HPR of uteri. Table 13 of our study shows that the women undergone TAH for suspected cases of adenomyosis $[\mathrm{n}=65(9.25 \%)]$ were most commonly in the age group of 40 to 49 years $[n=40(61.90)] .^{5,15}$

This is consistent with study of Chanderdeep Sharma, et al (2013) In this study peak occurrence of adenomyosis was observed in forth decade [ $\mathrm{n}=52(53.6 \%)]$, followed by fifth decade $[\mathrm{n}=17(17 \%)]$, followed by third decade $[\mathrm{n}=16(16 \%)]$. Vercellini P, Parazzini F, Oldani S, et.al. (1995) this study states that average age of symptomatic women of adenomyosis is usually older than 40 years, although occasionally noted in women in their younger reproductive years. ${ }^{15,22}$ Table 14 shows that the peak occurrence of adenomyosis was observed in women of parity 4 and parity $5[n=37(57.13 \%)]$. Followed by para 3 [n=60 (23.81\%)]. Vercellini P, Parazzini F, Oldani S, et al, Lee NC, et al, Templeman C, Marshall SF, Ursin G, et al, these study state that increasing parity, early menarche, and shorter menstrual cycle may all be risk factor according to study. Landholm C, Forsgren C et al, and Vercellini $\mathrm{P}$, Parazzini $\mathrm{F}$ et al, have similar observation. Figure 3 Endometriosis was observed in hysterectomy specimen in only $1.7 \%$ of all women with leiomyoma uterus, only $2.3 \%$ had associated endometriosis. . $7,17,22$ Studies that have analyzed the frequency of endometriosis in women who underwent surgery for leiomyoma have suggested a prevalence of about $10 \%$. Vercellini P, Parazzini $\mathrm{F}$ et al. ${ }^{22}$ in our observation the frequency of adenomyosis of women who underwent surgery for leiomyoma was $11.49 \%$, which is 
consistent with other observations. Our observation of this very low prevalence could be due to early marriage, early age of first pregnancy, high fertility rate, frequent teen-age pregnancy and protracted breast feeding observed in India. In this study Figure 4, 5, and 6 shows that there were another less common indication for TAH is recurrent post-menopausal bleeding $(1.76 \%, \mathrm{n}=13)$. Causes of post-menopausal bleeding were chronic cervicitis with intra epithelial neoplasia with adenomyosis in $[15.4 \% \quad(n=2)]$, senile atrophic endometrium with endometrial polyp [53.8\% $(n=7)]$ and chronic cervicitis with proliferative phase endometrium [30.8\% ( $n=4)]$. In studies of Pacheco JC et al, Hawwa JM et al, Lidor A et al and Fortier KJ (1986) possible uterine cause of perimenopausal or post-menopausal bleeding include endometrial atrophy (60\%-80\%) endometrial polyp (2\%-12\%), estrogen therapy (15\%-25\%), hyperplasia $(5 \%-10 \%)$ and cancer or sarcoma $(10 \%) .{ }^{18-21}$

\section{CONCLUSION}

In this retrospective study the most common indication for TAH for benign gynaecological condition is Fibroid Uterus $(49.78 \%)$ followed by abnormal uterine bleeding (11.01\%), followed by adenomyosis $(9.25 \%)$ followed by Ovarian mass $(8.81 \%)$ chronic cervicitis $(8.37 \%)$, AUB with Chronic cervicitis $(6.60 \%)$.

Majority of women requiring abdominal hysterectomy were in their fourth decade of life. Most of the women hailed from urban areas $(57.26 \%)$. Women of lower socio-economic status were associated with higher hysterectomy rates $(75 \%)$. The most common mode of presentation of women requiring abdominal hysterectomy was excessive, prolonged, frequent bleeding per vagina with pain $(58.14 \%)$. The most common HPR correlation of uteri of TAH were leiomyoma with chronic cervicitis $(49.78 \%)$, followed by chronic cervicitis (22.84\%) followed by adenomyosis with chronic cervicitis $(9.25 \%)$.

\section{ACKNOWLEDGEMENTS}

Author would like thanks to Associate Professors Dr. Mrs. Aruna Kumar (Professor and HOD), Dr. Mrs. Varuna Pathak (associate professor and guide), department of obstetrics and gynaecology, Gandhi Medical College Bhopal, for their excellent guidance and support.

\section{Funding: No funding sources}

Conflict of interest: None declared

Ethical approval: The study was approved by the Institutional Ethics Committee

\section{REFERENCES}

1. Baskett TF. Hysterectomy: evolution and trends. Best Pract Res Clin Obstet Gynecol. 2005;19:295305 .
2. Whiteman MK, Hillis SD, Jamieson DJ, Morrow B, Podgornik MN, Brett KM, Marchbanks PA. Inpatient hysterectomy surveillance in the United States, 20002004. American journal of obstetrics and gynecology. 2008;198(1):34.

3. Bower JK, Schreiner PJ, Sternfeld B, Lewis CE. Black-White differences in hysterectomy prevalence: The CARDIA Study. Am J public health. 2009; 99:300-7.

4. Cooper R, Lucke J, Lawlor DA, Mishra G, Chang $\mathrm{JH}$, Ebrahim S, et al. Socioeconomic position and hysterectomy: a cross-cohort comparison of women in Australia and Great Britain. Journal of epidemiology and community health. 2008;62(12):1057-63.

5. Varygas JM, Campeau JD, Mishell DR. Jr. Treatment of menorrhagia with meclofenamide sodium. Am J Obstet Gynecol. 1987;157:944-950.

6. Lee NC, Dikcer RC, Rubin GL. Confirmation of preoperative diagnosis for hysterectomy. Am J Obstet Gynecol 1984;150:283-287.

7. Templeman C, Marshall SF, Ursin G, Horn-Ross PL, Clarke CA, Allen M, et al. Adenomyosis and endometriosis in the California Teachers Study. Fertility and sterility. 2008;90(2):415-24.

8. Ballard LA, Walters MD. A transvaginal mobilization and removal of ovaries and fallopian tubes after vaginal hysterectomy. Obstet Gynecol 1996;87:35-39.

9. Walters MD, Barber MD. Complications of hysterectomy. In: Walters MD, Barber MD, eds. Hysterectomy for benign disease. Philadelphia, PA: Saunders, Elsevier, 2010:195-212.

10. Leung PL, Tsang SW, Yuen PM. Quality Assurance subcommittee in Obstetrics and Gynecology, Hospital Authority, Hongkong. An audit on hysterectomy for benign diseases in public hospitals in Hongkong. Hongkong Med J. 2007;13:187-93.

11. Onyeabochukwu DA, Duke-Onyeabo C, Onyegbule OA, Amajuoyi CC, Madu PI. A six year review of hysterectomy for benign gynaecological conditions at the Federal Medical Centre, Owerri. International Journal of Reproduction, Contraception, Obstetrics and Gynecology. 2017;3(2):352-6.

12. Omole-Ohonsi A, Muhammad Z, Lawan UM, Abubakar IS. Elective hysterectomy in Kano. Nig Clin Rev. 2005;9:26-30.

13. Orji EO, Ndukuba VI. Elective hysterectomy in Obafemi Awolowo University teaching hospital complex, ILE- Ife. Sahel Med J. 2002;5:95-8.

14. Gimbel H, Settnes A, Tabor A. Hysterectomy on benign indication in Denmark 1988-1998. A register based trend analysis. Acta Obstet Gynaecol. 2001; 80:267-72.

15. Sharma C, Sharma M, Raina R, Soni A, Chander B, Verma S. Gynecological diseases in rural India: A critical appraisal of indications and route of surgery along with histopathology correlation of 922 women undergoing major gynecological surgery. Journal of mid-life health. 2014;5(2):55. 
16. Peddada SD, Laughlin SK, Miner K, Guyon JP, Haneke K, Vahdat HL, et al. Growth of uterine leiomyomata among premenopausal black and white women. Proceedings of the National Academy of Sciences. 2008;105(50):19887-92.

17. Lundholm C, Forsgren C, Johansson AL, Cnattingius $\mathrm{S}$, Altman D. Hysterectomy on benign indications in Sweden 1987-2003: a nationwide trend analysis. Acta Obstet Gynecol Scand. 2009;88:52-8.

18. Pacheco JC, Kempers RD. Etiology of postmenopausal bleeding. Obstet Gynecol. 1968;32:40-6.

19. Hawwa ZM, Nahhas WA, Copenhaver EH. Postmenopausal bleeding. Lahey Clin Found Bull. 1970; 19:61-70.

20. Lidor A, Ismajovich B, Confino E, David MP. Histopathological findings in 226 women with post- menopausal uterine bleeding. Acta Obstet Gynecol Scand. 1986;65(1):41-3.

21. Fortier KJ. Postmenopausal bleeding and endometrium. Clin Obstet Gynecol 1986;29:440445.

22. Parazzini F, Vercellini P, Panazza S, Chatenoud L, Oldani S, Crosignani PG. Risk factor for adenomyosis. Hum Reprod. 1997;12:1275-9.

Cite this article as: Pathak V, Singh $P$, Tripathi A. Retrospective analytical study of total abdominal hyeterectomy for benign gynaecological conditions. Int J Reprod Contracept Obstet Gynecol 2017;6:1596-603. 